\title{
UJI SITOTOKSIK TUMBUHAN OBAT DI HUTAN ADAT SINAGA SUMATERA UTARA
}

\section{Cytotoxic Test of Drug Plants in The North Sumatera Sinaga Traditional Forest}

\author{
Riana Anggrainia ${ }^{\mathrm{a}}$ Albayudia ${ }^{\mathrm{a}}$, Nurli Sitohang ${ }^{\mathrm{a}}$ \\ Jurusan Kehutanan, Fakultas Pertanian, Universitas Jambi, Jl. Lintas Sumatera Jl. \\ Jambi Muara Bulian No.Km. 15, Mendalo Darat, Kec. Jambi Luar Kota, Kabupaten Muaro \\ Jambi, Jambi 36122, Indonesia \\ Email: nurlisitohang25@gmail.com,e-mail:nanuk_onra@yahoo.com
}

Diterima: 16 April 2021, Direvisi: 06 Juni 2021, Disetujui: 28 Januari 2022

DOI: 10.31849/forestra.v17i1.6531

\begin{abstract}
Toxicity test can be conduct Artemia salina shrimp larvae. Artemia salina larvae are simple organisms from marine life that are very small and have a high sensitivity to toxic. Most of the local people use medicinal plants for their daily needs and do not know about the medicinal compounds contained in these plants. Currently, a disease that is often found in Indonesian society is cancer. The cause of long-healing cancer is ineffective use of medicine and treatments, it is necessary to look for effective anticancer medicine that can eradicate cancer cells without damaging normal tissues by utilizing natural materials and have the potential to be used in the long term. The test results on plants showed extract from plant leaves was very toxic because it had a $L C_{50}$ value $<30 \mathrm{ppm}$, namely pirdot (Saurauria vulcanii) 3.9098 ppm, gandapura (Gaultheria leucocarpa) 4.1057 ppm, coffee parasites (Scurrula ferruginea) 16, 3735 ppm, avocado (Persea americana) 28.046 ppm, guava (Psidium guajava) $29.8296 \mathrm{ppm}$. Cytotoxic plants are concentrated $(0.2 \%, 0.1 \%, 0.05 \%$, $0.02 \%)$. Testing of secondary metabolites on five types of medicinal plants that contain phytochemicals with plant has alkaloid, flavonoid, phenolic, terpenoid, saponin compounds. flavonoids, terpenoids, saponins.
\end{abstract}

Key words: Artemia salina, LC50, secondary metabolites, toxicity

\section{ABSTRAK}

Uji toksisitas dapat dilakukan menggunakan larva udang Artemia salina. Larva Artemia salina merupakan organisme sederhana dari biota laut yang sangat kecil dan mempunyai kepekaan yang cukup tinggi terhadap toksik. Masyarakat sekitar sebagian besar memanfaatkan tumbuhan obat untuk kebutuhan sehari-hari dan tidak banyak mengetahui kandungan obat yang terkandung didalam tumbuhan tersebut. Saat ini penyakit yang banyak dijumpai pada masyarakat Indonesia yaitu penyakit kanker. Penyebab penyakit kanker lama sembuh karena tidak efektifnya penggunaan obat dan perawatan yang dilakukan, maka perlu 
dicari obat antikanker yang efektif dapat memberantas sel kanker tanpa merusak jaringanjaringan normal dengan memanfaatkan bahan alami serta memiliki potensi untuk dimanfaatkan dalam jangka panjang. Hasil uji pada tumbuhan menunjukkan ekstrak dari daun tumbuhan bersifat sangat toksik karena memiliki nilai $\mathrm{LC}_{50}<30 \mathrm{ppm}$ yaitu pirdot (Saurauria vulcanii) sebesar 3,9098 ppm, tumbuhan gandapura (Gaultheria leucocarpa) 4,1057 ppm, benalu kopi (Scurrula ferruginea) 16,3735 ppm, alpukat (Persea americana) 28,046 ppm, jambu biji (Psidium guajava) 29,8296 ppm. Kandungan konsentrasi sitotoksik tumbuhan $(0,2 \%, 0,1 \%, 0,05 \%, 0,02 \%)$. Pengujian metabolit sekunder pada lima jenis tumbuhan obat memiliki kandungan fitokimia dengan memiliki senyawa alkaloid, flavonoid, fenolik, terpenoid, saponin.

Kata kunci: Artemia salina, LC50, Metabolit sekunder, toksisitas.

\section{PENDAHULUAN}

Indonesia merupakan negara yang memiliki keanekaragaman hayati yang melimpah dan sangat berguna bagi masyarakat demi kelangsungan hidup. Keanekaragaman hayati dapat diartikan sebagai keanekaragaman kimiawi yang mampu menghasilkan bahan-bahan kimia, baik untuk kebutuhan manusia maupun organisme lain seperti untuk obat-obatan, insektisida, kosmetika dan sebagai bahan dasar sintesa senyawa organik yang lebih bermanfaat (Sukandar et al., 2008). Keanekaragaman hayati dapat berupa tumbuhan obat tradisional dan banyak diantaranya mempunyai potensi untuk dikembangkan menjadi sumberdaya ekonomi.

Pengetahuan tentang tumbuhan berkhasiat obat berdasar pada pengalaman dan ketrampilan yang secara turun temurun telah diwariskan dari satu generasi ke generasi berikutnya (Maria Tensiana Tima, 2020). Pengetahuan akan tumbuhan obat telah melekat dengan budaya masyarakat dan menjadi tradisi teknik penyembuhan dengan kearifan lokal yang memanfaatkan tumbuhan di sekitar hutan (Albertus et al., 2015).

Tumbuhan obat adalah semua spesies tumbuhan yang menghasilkan satu atau lebih komponen aktif yang digunakan untuk perawatan kesehatan dan pengobatan atau seluruh spesies tumbuhan yang diketahui atau dipercaya mempunyai khasiat obat (Harijanto et al., 2017). Masyarakat menggunakan tumbuhan obat karena beberapa alasan seperti tradisi upaya penyembuhan yang dilakukan 
masyarakat sangat tergantung pada budaya yang berlaku di masyarakat tersebut.

Saat ini penyakit yang banyak dijumpai pada masyarakat Indonesia yaitu penyakit kanker. Penyakit ini merupakan salah satu jenis penyakit yang disebabkan karena sel mengalami pertumbuhan yang tidak terkendali, karena sel kanker dapat memenuhi sinyal pertumbuhannya sendiri (Katili et al., 2015). Tumbuhan obat mampu mencegah penyakit tertentu dan relatif tidak memberikan dampak negatif bagi tubuh manusia dan berbagai bagian tumbuhan yang memiliki senyawa kimia yang khas (Albertus et al., 2015). Senyawa aktif yang terdapat dalam tumbuhan hampir selalu toksik pada dosis tinggi.

Toksisitas adalah kemampuan suatu zat kimia dalam menimbulkan kerusakan pada organisme baik saat digunakan atau saat berada dalam lingkungan (Fitrah dan Tahar, 2018). Uji toksisitas dilakukan untuk memperkirakan resiko yang berkaitan dengan pemaparan zat kimia dalam kondisi khusus karena kita ketahui bahwa tidak ada satupun zat kimia yang dikatakan aman (bebas resiko) sepenuhnya, karena zat kimia akan bersifat toksik pada tingkat dosis tertentu ( $\mathrm{Lu} 2006$ dalam
Fitrah dan Tahar, 2018). Uji toksisitas dapat dilakukan dengan menggunakan larva udang Artemia salina. Larva Artemia salina merupakan organisme sederhana dari biota laut yang sangat kecil dan mempunyai kepekaan yang cukup tinggi terhadap toksik (Pujiati et al., 2006 dalam Hassan, 2007). Selain itu, Artemia salina memiliki keistimewaan yaitu memiliki toleransi (kemampuan beradaptasi) pada kisaran garam yang sangat luas, waktu siklus hidup yang lebih cepat dan mudah dibiakan (Sinaga et al., 2018).

Hutan Adat Sinaga merupakan kawasan hutan yang memiliki tumbuhan obat yang dapat dimanfaatkan masyarakat sekitar sebagai obat dan juga dapat dimanfaatkan sebagai sumberdaya ekonomi. Kawasan Hutan Adat Sinaga merupakan kawasan yang terletak di Kabupaten Samosir, Sumatera Utara dengan kondisi yang memiliki keanekaragaman jenis tumbuhan obat. Masyarakat sekitar sebagian besar memanfaatkan tumbuhan obat untuk kebutuhan sehari-hari dan tidak banyak yang menggunakan sebagai obat dan tidak banyak mengetahui kandungan obat yang terkandung didalam tumbuhan tersebut. 
Tujuan penelitian dilakukan untuk mengidentifikasi lima jenis tumbuhan obat yang ada di Hutan Adat Sinaga dan mengkaji kandungan bioaktivitas dari lima jenis tumbuhan obat antikanker sebagai sitotoksik yang digunakan masyarakat sekitar Kawasan Hutan Adat Sinaga.

\section{METODE PENELITIAN}

\subsection{Waktu dan Tempat}

Penelitian dilaksanakan dari bulan Mei sampai dengan November 2020 berlokasi di Hutan Adat Sinaga Sumatera Utara dan di Laboratorium Terpadu Universitas Jambi.

\subsection{Alat dan Bahan}

Alat dan bahan yang digunakan adalah hammer mill, saringan mesh 40-60 mesh, rotary evaporator, toples kaca, batang pengaduk, corong, tabung reaksi, oven, gelas ukur, desikator, kaca pembesar, erlenmeyer, pipet tetes, petridish, oven, lampu, botol amber, gunting, carter, lakban hitam, botol aqua, selang aquarium, air pump, spidol permanen, alat tulis, kamera dan lima jenis tumbuhan yang berpotensi sebagai bahan obat antikanker, telur udang Artemia salina Leach \pm 750 telur, $\mathrm{HCl}$, $\mathrm{HCl} 0,2 \mathrm{~N}, \mathrm{HCl} 2 \mathrm{~N}, \mathrm{CH}_{3} \mathrm{COOH}, \mathrm{CHCl}_{3}$, $\mathrm{H}_{2} \mathrm{SO}_{4}, \mathrm{FeCl}_{3}, \mathrm{FeCl}_{3} 5 \%$, pita $\mathrm{Mg}$, pereaksi Dragendorff, pereaski mayer, pereaksi wager, air laut, aquades dan etanol $70 \%$ sebagai pelarut.

\subsection{Metode Pengumpulan Data}

Metode pengumpulan data yang dilakukan adalah wawancara. Teknik wawancara yang dilakukan yaitu dengan menggunakan teknik wawancara snowball, yaitu suatu pendekatan dengan masyarakat yang memiliki banyak informasi atau informan kunci. Kriteria dalam penentuan informan kunci adalah informan yang mengetahui tentang informasi yang dibutuhkan dalam penelitian. Tahap pengambilan sampel tumbuhan obat dilakukan dengan kegiatan setiap spesimen tumbuhan obat yang ditemukan di Kawasan Hutan Adat Sinaga didokumentasikan, mendeskripsikan ciriciri morfologi jenis tumbuhan obat yang ditemukan pada daerah tersebut, mengidentifikasi spesimen tumbuhan obat yang telah ditemukan dilakukan dengan cara membandingkan deskripsi dan gambarnya pada literatur, melakukan studi pustaka dan diambil lima jenis tumbuhan obat sebagai antikanker yang digunakan masyarakat untuk obat kanker.

\subsection{Persiapan Bahan Baku}


Persiapan bahan baku adalah bagian daun dari lima tumbuhan obat yang digunakan sebagai obat antikanker diambil dari lapangan dan kemudian dikeringudarakan sampai kadar airnya (11$12 \%)$ kemudian digiling menggunakan hammer mill. Serbuk yang diperoleh kemudian disaring menggunakan alat saring mesh screen. Serbuk berukuran 4060 mesh sebanyak \pm 200 gram diperlukan untuk ekstraksi. Ekstraksi dengan etanol yaitu metode ekstraksi yang digunakan mengacu pada (Suhendra et al., 2019) yaitu maserasi yang menggunakan pelarut etanol $70 \%$ dan dilakukan pada suhu kamar. Serbuk sampel sebanyak $\pm 200 \mathrm{~g}$ dari bagian tumbuhan obat ditempatkan pada toples kaca besar dan diekstraksi menggunakan pelarut etanol $70 \%$ dengan perbandingan serbuk dan pelarut yakni 1:10. Ekstraksi dilakukan selama 24 jam. Proses tersebut diulang hingga hasil saringan maserasi tidak berwarna. Selanjutnya filtrate hasil maserasi dipekatkan dengan rotary evaporator pada suhu $60{ }^{\circ} \mathrm{C}$ dan kecepatan $50 \mathrm{rpm}$, sebanyak $5 \mathrm{ml}$, hasil pekatan dikeringkan pada suhu $50{ }^{\circ} \mathrm{C}$ selama 6 jam untuk menentukan rendemen dan sisanya dikeringkan untuk dilakukan pengujian analisis ekstrak etanol dengan metode Brine Shrimp Lethality Test dan analisis senyawa kimia dengan metabolit sekunder.

\subsection{Uji Sitotoksik Menggunakan Metode Brine Shrimp Lethality Test (BSLT)}

Pengujian metode Brine Shrimp Lethality Test (BSLT), penetasan larva artemia dilakukan dengan memasukkan air laut dan larva udang artemia salina dalam wadah kemudian dibiarkan selama 48 jam. Pengujian toksisitas dilakukan sebanyak 3 kali ulangan dengan konsentrasi yang berbeda-beda dari masing-masing ekstrak. Jumlah larutan induk sebanyak $100 \mathrm{ml}$ air laut $(5 \mathrm{mg} / \mathrm{ml})$, kemudian 10 ekor larva dimasukkan kedalam masing-masing botol vial, dengan konsentrasi yang digunakan adalah $0,2 \%, 0,5 \%, 0,15 \%, 0,05 \%, 0,02 \%$. Setelah itu dilakukan pengamatan selama 24 jam untuk melihat yang hidup dan yang mati dan dilakukan analisis data dengan analisis probit selang kepercayaan $95 \%$. Nilai LC50 merupakan konsentrasi dimana zat menyebabkan kematian 50\% yang diperoleh dengan memakai persamaan regresi linier $y=a+b x$. Suatu zat dikatakan aktif atau toksik bila nilai LC50 $<1000$ ppm untuk ektrak dan < 30 ppm untuk suatu senyawa (Ajrina, 2013). 


\subsection{Uji Metabolit Sekunder}

a. Uji Alkaloid

Ekstrak dilarutkan dengan $1 \mathrm{ml}$ larutan $\mathrm{HCl}$ 0,2 $\mathrm{N}$ dan $9 \mathrm{ml}$ aquades kemudian dipanaskan dan disaring. Filtrat dibagi kedalam 3 tabung reaksi. Tabung pertama ditambahkan 3 tetes pereaksi Dragendorff. Tabung kedua ditambahkan 3 tetes pereaksi Mayer. Tabung ketiga ditambahkan 3 tetes pereaksi Wagner. Ekstrak mengandung alkaloid jika terbentuk endapan jingga pada tabung pertama, endapan putih kekuningan pada tabung kedua dan endapan coklat muda sampai kuning pada tabung ketiga (Jazilah et al., 2014).

\section{b. Uji Flavonoid}

Ekstrak dilarutkan dengan $10 \mathrm{~mL}$ air hangat kemudian dididihkan selama 5 menit lalu disaring. Filtrat sebanyak $5 \mathrm{~mL}$ ditambahkan pita $\mathrm{Mg}$ dan $1 \mathrm{~mL} \mathrm{HCl}$ pekat kemudian dikocok. Ekstrak mengandung flavonoid jika terbentuk endapan merah (Jazilah et al., 2014).

c. Uji Fenolik

Uji Fenol Hidrokuinon (pereaksi $\mathrm{FeCl}_{3}$ ) sebanyak $1 \mathrm{~g}$ sampel diekstrak dengan $20 \mathrm{ml}$ etanol 70\%. Ekstrak sebanyak $1 \mathrm{ml}$ kemudian ditambahkan 2 tetes larutan $\mathrm{FeCl}_{3}$ 5\%. Pembentukan warna hijau atau hijau biru menunjukkan senyawa fenol dalam bahan (Manongko et al., 2020).

\section{d. Uji Terpenoid}

Pengujian dilakukan dengan cara mengambil ekstrak sebanyak $2 \mathrm{ml}$ sampel yang telah diekstraksi dengan pelarut etanol. Setelah itu ekstrak ditambahkan dengan 1 tetes $\mathrm{H}_{2} \mathrm{SO}_{4}$ pekat. Jika larutan terbentuk warna merah atau ungu maka positif mengandung terpenoid (Manongko et al., 2020).

\section{e. Uji Steroid}

Ekstrak dilarutkan dengan $0,5 \mathrm{ml}$ kloroform dan ditambahkan $0,5 \mathrm{ml}$ asam asetat, kemudian $2 \mathrm{ml}$ asam sulfat pekat ditambahkan melalui dinding tabung. Ekstrak mengandung steroid jika terbentuk cincin biru kehijauan dan cincin kecoklatan jika mengandung triterpenoid (Manongko et al., 2020).

\section{f. Uji Saponin}

Ekstrak dilarutkan dengan $10 \mathrm{ml}$ air hangat, didinginkan kemudian dikocok selama 10 detik, ditambahkan 1 tetes larutan $\mathrm{HCl} 2 \mathrm{~N}$. Ekstrak mengandung saponin jika terbentuk busa yang stabil 
setinggi $1-10 \mathrm{~cm}$ selama tidak kurang dari 10 menit (Manongko et al., 2020).

Analisis data untuk penelitian ini adalah analisis data dengan analisis probit $\mathrm{LC}_{50}$ dengan selang kepercayaan $95 \%$. $\mathrm{LC}_{50}$ adalah konsentrasi ekstrak yang mampu mematikan $50 \%$ populasi larva udang diujikan.

\section{HASIL DAN PEMBAHASAN}

\subsection{Data Hasil Wawancara Tumbuhan Obat}

Wawancara dengan masyarakat di Hutan Adat Sinaga dengan responden 19 orang yaitu kriteria yang menggunakan tumbuhan obat atau dapat disebut tabib. Adapun hasil wawancara mengenai jenis tumbuhan obat beserta kegunaannya disajikan dalam Tabel 1.

Tabel 1. Hasil wawancara jenis tumbuhan di sekitar Hutan Adat Sinaga

\begin{tabular}{|c|c|c|c|c|c|c|}
\hline No & Famili & Nama Latin & Nama Lokal & $\begin{array}{c}\text { Bagian yang } \\
\text { Digunakan }\end{array}$ & $\begin{array}{c}\text { Cara } \\
\text { Penggunaan } \\
\end{array}$ & Khasiat \\
\hline 1 & Actinidiaceae & Saurauia vulcanii L. & Pirdot & Daun & $\begin{array}{l}\text { Direbus, } \\
\text { Ditumbuk, } \\
\text { Diminum }\end{array}$ & $\begin{array}{l}\text { Obat } \\
\text { kanker }\end{array}$ \\
\hline 2 & Acoraceae & Calamus caesius & Rotan & Akar & $\begin{array}{l}\text { Direbus, } \\
\text { Dimandikan }\end{array}$ & $\begin{array}{l}\text { Obat } \\
\text { asam urat }\end{array}$ \\
\hline 3 & Apiaceae & Centella asiatica $\mathrm{L}$. & Pegagan & Daun & $\begin{array}{l}\text { Direbus, } \\
\text { Dimandikan }\end{array}$ & $\begin{array}{l}\text { Obat } \\
\text { maag }\end{array}$ \\
\hline 4 & Asteraceae & Ageratum conyzoides L. & Bandotan & Daun & $\begin{array}{l}\text { Direbus, } \\
\text { Dimandikan, } \\
\text { Diminum }\end{array}$ & $\begin{array}{l}\text { Obat } \\
\text { asam urat, } \\
\text { maag }\end{array}$ \\
\hline 5 & Asteraceae & Choromolaena odorata $\mathrm{L}$. & Kirinyuh & Daun & $\begin{array}{l}\text { Direbus, } \\
\text { Dimandikan, } \\
\text { Diminum, } \\
\text { Dioles }\end{array}$ & $\begin{array}{l}\text { Obat } \\
\text { maag, } \\
\text { luka }\end{array}$ \\
\hline 6 & Asteraceae & $\begin{array}{l}\text { Crassocephalum } \\
\text { crepidioides }\end{array}$ & Sintrong & Daun & $\begin{array}{l}\text { Direbus, } \\
\text { Dimandikan }\end{array}$ & $\begin{array}{l}\text { Obat } \\
\text { penurun } \\
\text { tensi }\end{array}$ \\
\hline 7 & Asteraceae & Gynura rocumbens L. & $\begin{array}{l}\text { Penyambung } \\
\text { nyawa }\end{array}$ & Daun & $\begin{array}{l}\text { Direbus, } \\
\text { Diminum }\end{array}$ & $\begin{array}{l}\text { Obat } \\
\text { maag }\end{array}$ \\
\hline 8 & Asteraceae & Lactuca indica $\mathrm{L}$. & Tempuyung & Daun & $\begin{array}{l}\text { Direbus, } \\
\text { Diminum }\end{array}$ & $\begin{array}{l}\text { Obat } \\
\text { batuk, } \\
\text { maag }\end{array}$ \\
\hline No & Famili & Nama Latin & Nama Lokal & $\begin{array}{c}\text { Bagian yang } \\
\text { Digunakan }\end{array}$ & $\begin{array}{c}\text { Cara } \\
\text { Penggunaan } \\
\end{array}$ & Khasiat \\
\hline 9 & Asteraceae & Tithonia diversifolia & $\begin{array}{l}\text { Kembang } \\
\text { bulan }\end{array}$ & Daun & $\begin{array}{l}\text { Direbus, } \\
\text { Diminum, } \\
\text { Dioles }\end{array}$ & $\begin{array}{l}\text { Obat } \\
\text { maag }\end{array}$ \\
\hline 10 & $\begin{array}{l}\text { Convolvulace } \\
\text { ae }\end{array}$ & Ipomea batatas $\mathrm{L}$. & Ubi jalar & Daun & $\begin{array}{l}\text { Direbus, } \\
\text { Dimandikan, } \\
\text { Diminum }\end{array}$ & $\begin{array}{l}\text { Obat } \\
\text { maag }\end{array}$ \\
\hline 11 & Cyatheaceae & Cyathea contaminans & Tanggiang & Daun, Buah & $\begin{array}{l}\text { Dibakar, } \\
\text { Dioleskan }\end{array}$ & $\begin{array}{l}\text { Obat } \\
\text { Terbakar }\end{array}$ \\
\hline 12 & Ericaceae & Gaultheria leucocarpa & Gandapura & Daun & $\begin{array}{l}\text { Direbus, } \\
\text { Dimandikan, }\end{array}$ & $\begin{array}{l}\text { Obat } \\
\text { kanker, }\end{array}$ \\
\hline
\end{tabular}


Wahana Forestra: Jurnal Kehutanan Vol. 17 No. 1 Januari 2022

\begin{tabular}{|c|c|c|c|c|c|c|}
\hline & & & & & Diminum & influenza \\
\hline 13 & Lauraceae & Persea americana & Alpukat & Daun & $\begin{array}{l}\text { Direbus, } \\
\text { Dimandikan, } \\
\text { Diminum }\end{array}$ & $\begin{array}{l}\text { Obat } \\
\text { kanker, } \\
\text { batuk }\end{array}$ \\
\hline 14 & Loranthaceae & Scurrula ferruginea & Benalu kopi & Daun & $\begin{array}{l}\text { Direbus, } \\
\text { Dimandikan, } \\
\text { Diminum }\end{array}$ & $\begin{array}{l}\text { Obat } \\
\text { kanker }\end{array}$ \\
\hline 15 & Malvaceae & Hibiscus rosa-sinensis $L$. & $\begin{array}{l}\text { Kembang } \\
\text { sepatu }\end{array}$ & Daun & $\begin{array}{l}\text { Diperas } \\
\text { Diminum }\end{array}$ & $\begin{array}{l}\text { Obat } \\
\text { maag, } \\
\text { kontraksi }\end{array}$ \\
\hline 16 & Malvaceae & Sida rhombifolia Linn. & Sidaguri & Daun, akar & $\begin{array}{l}\text { Direbus, } \\
\text { Dimandikan, } \\
\text { Diminum }\end{array}$ & $\begin{array}{l}\text { Obat } \\
\text { asam urat }\end{array}$ \\
\hline 17 & $\begin{array}{l}\text { Melastomatac } \\
\text { eae }\end{array}$ & Melastoma affine D. & Senduduk & Daun & $\begin{array}{l}\text { Direbus, } \\
\text { Dimandikan }\end{array}$ & $\begin{array}{l}\text { Obat } \\
\text { maag, } \\
\text { disentri }\end{array}$ \\
\hline 18 & Musaceae & Musa paradisiaca $\mathrm{L}$. & Pisang kepok & $\begin{array}{l}\text { Buah, } \\
\text { Batang }\end{array}$ & $\begin{array}{l}\text { Direbus, } \\
\text { Diminum }\end{array}$ & $\begin{array}{l}\text { Obat } \\
\text { maag, } \\
\text { disentri }\end{array}$ \\
\hline 19 & Myrtaceae & Eucalyptus sp. & Eukaliptus & Daun & $\begin{array}{l}\text { Direbus, } \\
\text { Dimandikan }\end{array}$ & $\begin{array}{l}\text { Obat } \\
\text { influenza }\end{array}$ \\
\hline 20 & Myrtaceae & Psidium guajava & Jambu biji & Daun & $\begin{array}{l}\text { Direbus, } \\
\text { Diminum }\end{array}$ & $\begin{array}{l}\text { Obat } \\
\text { kanker, } \\
\text { maag }\end{array}$ \\
\hline 22 & Poaceae & Cymbopogon citratus & Serai & Daun & $\begin{array}{l}\text { Direbus, } \\
\text { Dimandikan }\end{array}$ & $\begin{array}{l}\text { Obat } \\
\text { kejang }\end{array}$ \\
\hline 23 & Poaceae & Imperata cylindrica & Ilalang & Akar & $\begin{array}{l}\text { Direbus, } \\
\text { Dimandikan }\end{array}$ & $\begin{array}{l}\text { Obat } \\
\text { hipertens, } \\
\text { panas } \\
\text { dalam }\end{array}$ \\
\hline 24 & Solanaceae & Physalis angulate $\mathrm{L}$. & Ciplukan & Daun, buah & $\begin{array}{l}\text { Direbus, } \\
\text { Dimandikan }\end{array}$ & $\begin{array}{l}\text { Obat } \\
\text { cacar air }\end{array}$ \\
\hline 25 & Zingiberaceae & Etlingera elatior & Kecombrang & Buah & $\begin{array}{l}\text { Diperas, } \\
\text { diminum }\end{array}$ & $\begin{array}{l}\text { Obat } \\
\text { batuk }\end{array}$ \\
\hline
\end{tabular}

Hasil penelitian diketahui bahwa tumbuhan yang ada ditemukan di Hutan Adat Sinaga memiliki berbagai macam spesies dan famili. Famili tumbuhan yang banyak ditemukan ialah famili Asteracae. Bagian tumbuhan yang banyak digunakan dari tumbuhan yang didapatkan adalah bagian daunnya. Penggunaan bagian tumbuhan banyak digunakan dengan cara direbus. Khasiat tumbuhan tersebut juga berbagai macam yaitu untuk obat maag, kanker, luka, asam urat, disentri, obat batuk, kejang-kejang, influenza dan cacar air. Setelah dilakukan wawancara dan juga berdasarkan literatur dengan atlas tumbuhan diambil lima jenis tumbuhan dari 25 tumbuhan sebagai obat yang berpotensi sebagai obat kanker.

\subsection{Tumbuhan Obat Potensial Sebagai Anti Kanker di Hutan Adat Sinaga}

a. Gandapura (Gaultheria leucocarpa)

Klasifikasi tumbuhan Gandapura (Gaultheria leucocarpa) sebagai berikut: 
Kingdom: Plantae, Divisi: Magnoliophyta, Kelas: Magnoliopsida, Ordo: Ericales, Suku: Ericaceae, Genus: Gaultheria, Spesies: Gaultheria leucocarpa. Bagian tumbuhan sae-sae atau gandapura ini yang berpotensi sebagai obat antikanker adalah bagian daunnya dengan pengolahan daun direbus kemudian airnya diminum. Manfaat lain dari tumbuhan ini adalah sebagai obat untuk merefleksikan badan, obat infuenza, obat demam, peradangan dan penyembuhan luka. Cara pengolahannya adalah dengan merebus daun dan batang dan buah dari tumbuhan sae-sae kemudian membiarkan sampai dingin dan dimandikan.

a. Jambu biji (Psidium guajava)

Klasifikasi tumbuhan jambu biji (Anonymous, 2006) sebagai berikut: Kingdom: Plantae, Divisi: Magnolyophyta, Kelas: Magnolyopsida, Ordo: Myrtales: Famili: Myrtaceae, Genus: Psidium, Spesies: Psidium guajava L. Jambu biji (Psidium guajava L.). Bagian tumbuhan jambu biji yang berpotensi sebagai obat antikanker adalah bagian daunnya. Cara pengolahan daunnya ialah direbus dengan air kemudian didinginkan dan diminum. Manfaat lain dari tumbuhan jambu biji adalah sebagai obat maag, obat disentri yaitu dengan memakan langsung daun jambu tersebut tanpa melakukan pengolahan apapun.

\section{b. Pirdot (Saurauria vulcanii Korth)}

Klasifikasi tumbuhan pirdot sebagai berikut: Kingdom: Plantae, Famili: Actinidaceae, Divisi: Spermatophyte, Kelas: Magnoliopsida, Ordo: Theales, Genus: Saurauria, Spesies: Saurauria vulcanii. Korth. Bagian tumbuhan pirdot yang berpotensi sebagai obat anti kanker adalah bagian daunnya. Cara pengolahan daunnya ialah pucuk daun sebanyak 5 lembar ditumbuk kemudian diaduk dalam air minum yang hangat satu gelas dan disaring, hasil saringannya diminum. Manfaat lain dari tumbuhan pirdot adalah sebagai obat maag, obat disentri yaitu dengan merebus daunnya dan meminum hasil dari rebusan daun tersebut dan dapat juga ditumbuk.

c. Benalu kopi (Scurrula ferruginea)

Klasifikasi benalu kopi menurut Putra (2015) sebagai berikut: Kingdom: Plantae, Divisi: Magnoliopsida, Ordo: Santales, Famili: Loranthaceae, Genus: Loranthus, Spesies: Scurrula ferruginea (Jack) Danser. Bagian tumbuhan sariddan yang 
digunakan sebagai obat antikanker ialah bagian daunnya. Cara pengolahannya ialah dengan merebus daun dari sariddan kemudian air rebusan diminum. Manfaat lain dari tumbuhan ini adalah sebagai bubuk teh, obat sakit maag, dan obat batuk yang digunakan oleh masyarakat. Cara penggunaannya ialah dengan merebus daun dan batang tumbuhan kemudian meminum air dari hasil rebusan, tetapi dapat juga dimandikan.

\section{d. Alpukat (Persea americana)}

Klasifikasi tumbuhan alpukat menurut ITIS (2015) adalah sebagai berikut: Kingdom: Plantae, Divisi: Tracheophyta, Kelas: Magnoliopsida, Ordo: Laurales, Famili: Lauracea, Genus: Persea Mill, Spesies: Persea americana Mill. Bagian tumbuhan alpukat digunakan sebagai obat antikanker adalah daunnya dengan pengolahan daun direbus dan diminum. Manfaat lain dari tumbuhan ini adalah sebagai obat batuk dengan menumbuk daun kemudian air perasannya diminum.

\subsection{Pengujian Toksisitas dengan Metode Brine Shrimp Lethality Test}

Metode yang sering digunakan dalam mengetahui efek toksik suatu senyawa adalah dengan melakukan metode pengujian Brine Shrimp Lethality Test (BSLT). Pengujian toksisitas pada penelitian ini menggunakan larva, karena pada saat itu membelah secara mitosa yang identik dengan sel kanker yang juga membelah secara mitosis. Hal ini menyebabkan uji BSLT sering digunakan sebagai uji pendahuluan aktivitas antikanker yang dapat menyebabkan kematian pada sel (Harijanto et al., 2017).

Setelah dilakukan perhitungan dengan memasukkan nilai y sebesar 5 pada setiap sampel maka diperoleh hasil probit analisis $\mathrm{LC}_{50}$ tumbuhan yang disajikan dalam bentuk grafik hasil analisis regresi probit $\mathrm{LC}_{50}$ dari 5 jenis tumbuhan disajikan sebagai berikut: 


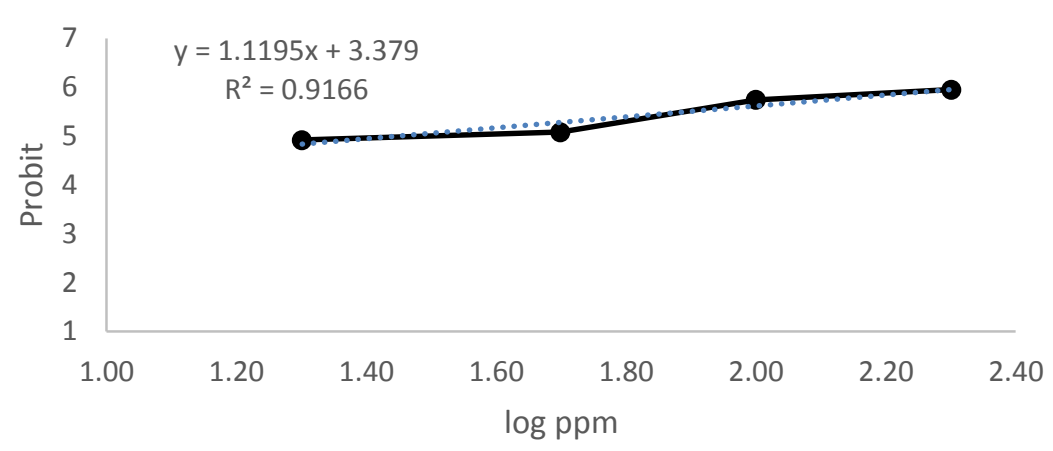

Gambar 1. Grafik hasil probit analisis $\mathrm{LC}_{50}$ tumbuhan alpukat (Persea americana)

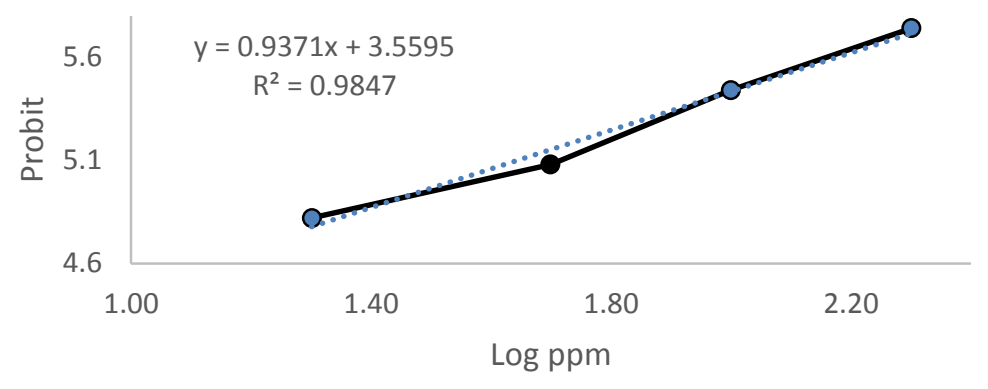

Gambar 2. Grafik hasil probit analisis $\mathrm{LC}_{50}$ tumbuhan jambu biji (Psidium guajava)

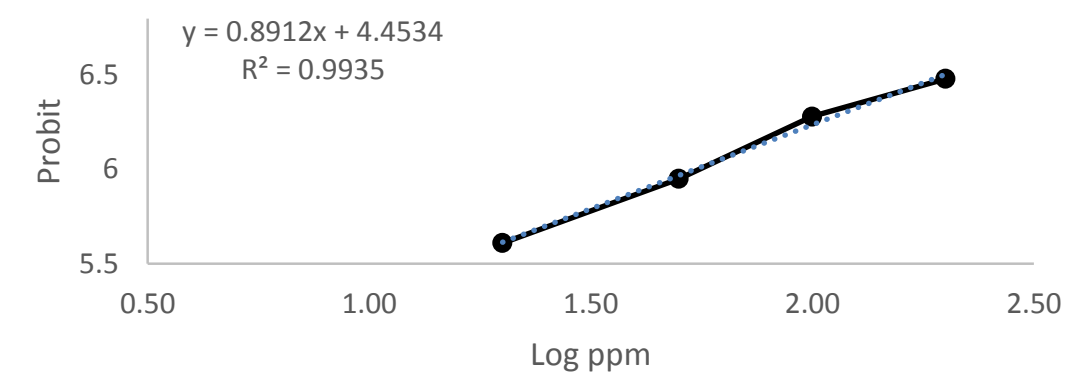

Gambar 3. Grafik hasil probit analisis $\mathrm{LC}_{50}$ tumbuhan gandapura (Gaultheria leucocarpa)

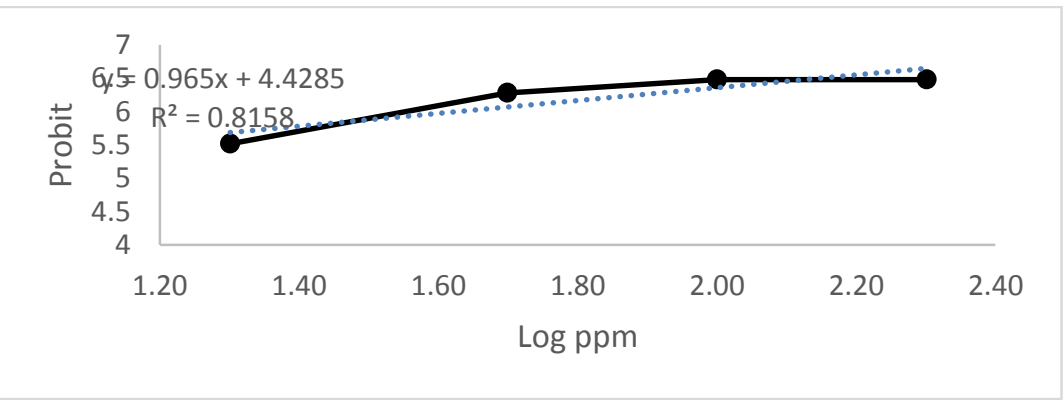


Gambar 4. Grafik hasil probit analisis $\mathrm{LC}_{50}$ tumbuhan pirdot (Saurauia vulcanii)

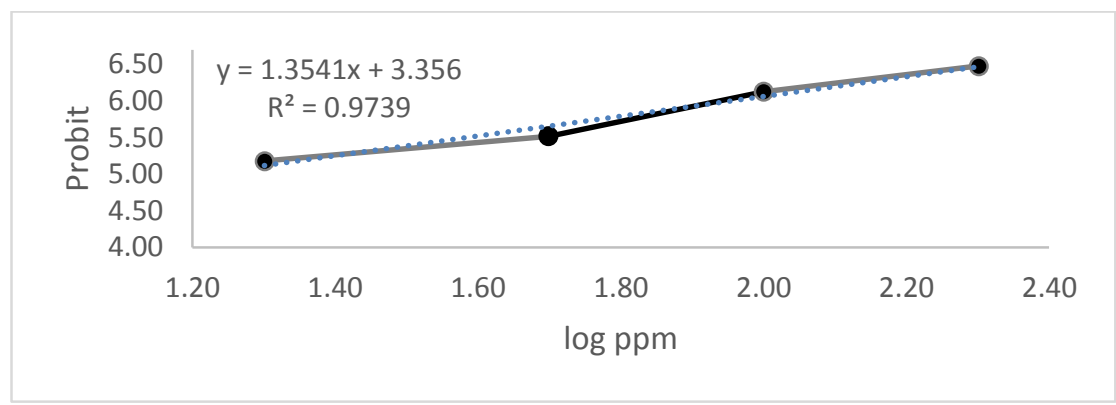

Gambar 5. Grafik hasil probit analisis $\mathrm{LC}_{50}$ tumbuhan benalu kopi (Scurrula ferruginea)

Hasil probit analisis LC50 dari kelima tumbuhan berpotensi antikanker dapat diketahui bahwa grafik tersebut menunjukkkan nilai log konsentrasi

Tabel 2. Hasil uji toksisitas metode Brine

Shrimp Lethality Test (BSLT) terhadap nilai probit yang didapat dari presentasi kematian larva. Semakin tinggi konsentrasi ekstrak, maka sifat toksik tumbuhan semakin tinggi.

\begin{tabular}{|c|c|c|c|c|c|c|c|c|c|c|c|}
\hline Nama & Konsentrasi & $\mathbf{U} \mathbf{1}$ & $\mathbf{U} 2$ & $\mathbf{U 3}$ & Jumlah & Total & Mortalita\$, 2 & Ppm & $\underset{\text { ppm }}{1 \text { dog }} 9$ & Probit & 28 \\
\hline \multirow{4}{*}{$\begin{array}{l}\text { Daun alpukat } \\
\quad \text { (Persea } \\
\text { americana })\end{array}$} & 0,2 & 9 & 8 & 8 & & Daun pltdot & $83 \% \quad 0,1$ & 200 & 12,309 & 5,95 & 28 \\
\hline & 0,1 & 8 & 8 & 7 & \multicolumn{2}{|c|}{$23^{\text {(Saurauia vulcanii) }}$} & $77 \% 0,05$ & 100 & 12,008 & $5,7_{4}$ & 27 \\
\hline & 0,05 & 6 & 6 & 4 & 16 & 30 & $53 \% \quad 0,02$ & 50 & $8_{1,70} 7$ & 5,68 & 21 \\
\hline & 0,02 & 5 & 5 & 4 & 14 & 30 & $47 \% \quad 0,2$ & 20 & 19,309 & 4,92 & 28 \\
\hline \multirow{4}{*}{$\begin{array}{l}\text { Daun jambu biji } \\
\text { (Psidium guajava) }\end{array}$} & 0,2 & 8 & 8 & 7 & \multicolumn{2}{|c|}{$\begin{array}{c}23 \\
23 a u n \text { benglu kopi } \\
\text { (Scurrula }\end{array}$} & $77 \% \quad 0,1$ & 200 & $12,30^{8}$ & $5,7_{4}^{8}$ & 26 \\
\hline & 0,1 & 8 & 6 & 6 & \multicolumn{2}{|c|}{20 ferrugigea } & $67 \% \quad 0,05$ & 100 & $7_{2,00}^{8}$ & 5,44 & 21 \\
\hline & 0,05 & 5 & 6 & 5 & \multicolumn{2}{|r|}{30} & $53 \% \quad 0,02$ & 50 & $5_{1,70} 6$ & 5,08 & 17 \\
\hline & 0,02 & 5 & 5 & 4 & 14 & 30 & $47 \%$ & 20 & 2,30 & 4,92 & \\
\hline Daun gandapura & 0,2 & 10 & 9 & 9 & 28 & 30 & $93 \%$ & 200 & 2,30 & 6,48 & \\
\hline \multicolumn{5}{|c|}{ Hasil uji pada tumbuhan menunjukkan } & \multicolumn{6}{|c|}{ pirdot (Saurauria vulcanii) sebesar 3,9098 } & \\
\hline \multicolumn{5}{|c|}{ bahwa ekstrak dari daun tumbuhan bersifat } & \multicolumn{6}{|c|}{ ppm, benalu kopi (Scurrula ferruginea) } & \\
\hline \multirow{2}{*}{\multicolumn{5}{|c|}{$\begin{array}{l}\text { sangat toksik karena memiliki nilai } \mathrm{LC}_{50} \\
<30 \text { ppm yaitu tumbuhan gandapura }\end{array}$}} & \multicolumn{6}{|c|}{ 16,3735 ppm, alpukat (Persea americana) } & \\
\hline & & & & & \multicolumn{6}{|c|}{ 28,046 ppm, jambu bij (Psidium guajava) } & \\
\hline \multicolumn{5}{|c|}{ (Gaultheria leucocarpa) 4,1057 ppm, } & \multicolumn{6}{|c|}{29,8296 ppm. } & \\
\hline
\end{tabular}


Semakin kecil nila $\mathrm{R}$ square $\left(\mathrm{R}^{2}\right)$ maka pengaruh probit terhadap log konsentrasi semakin lemah dan sebaliknya jika nilai $\mathrm{R}$ square mendekati angka 1 maka pengaruh nilai probit terhadap log konsentrasi semakin kuat (Febriyani, 2020).

\subsection{Uji Toksisitas Metode Brine Shrimp Lethality Test}

Uji metabolit sekunder yang dilakukan adalah uji alkaloid, flavonoid, fenolik, terpenoid, steroid dan saponin. Hasil uji metabolit sekunder ini diberikan tanda setelah diuji, yaitu tanda positif (+) menandakan bahwa didalam tumbuhan tersebut mengalami perubahan dan negatif (-) tidak mengalami perubahan setelah dilakukan uji metabolit sekunder atau dengan kata lain ekstrak tidak memiliki warna atau tanda yang berubah. Hasil uji metabolit sekunder lima tumbuhan obat potensial sebagai anti kanker disajikan pada Tabel 3.

Tabel 3. Hasil uji metabolit sekunder lima jenis tumbuhan potensial anti kanker

\begin{tabular}{|c|c|c|c|c|c|c|c|}
\hline \multirow[b]{2}{*}{ No } & \multirow[b]{2}{*}{ Tumbuhan } & \multicolumn{6}{|c|}{ Uji Metabolit Sekunder } \\
\hline & & $\begin{array}{l}\text { Uji Alkaloid } \\
\text { (Meyer dan } \\
\text { Dragendorf) }\end{array}$ & $\begin{array}{c}\text { Uji } \\
\text { Flavonoid } \\
\text { (Mg dan } \\
\text { HCl) }\end{array}$ & $\begin{array}{l}\text { Uji Fenolik } \\
\quad\left(\mathrm{FeCl}_{3}\right)\end{array}$ & $\begin{array}{c}\text { Uji } \\
\text { Terpenoid } \\
\left(\mathrm{H}_{2} \mathrm{SO}_{4}\right)\end{array}$ & $\begin{array}{l}\text { Uji Steroid } \\
\left(\mathrm{H}_{2} \mathrm{SO}_{4}\right)\end{array}$ & $\begin{array}{c}\text { Uji } \\
\text { Saponin } \\
(\text { HCl 2N) }\end{array}$ \\
\hline 1 & $\begin{array}{c}\text { Gandapura (Gaultheria } \\
\text { leucocarpa) }\end{array}$ & - & + & + & + & - & + \\
\hline 2 & $\begin{array}{c}\text { Alpukat (Persea } \\
\text { americana) }\end{array}$ & + & + & + & - & + & + \\
\hline 3 & $\begin{array}{c}\text { Jambu bji (Psidium } \\
\text { guajava) }\end{array}$ & + & + & + & - & + & + \\
\hline 4 & $\begin{array}{c}\text { Benalu kopi (Scurrula } \\
\text { ferruginea) }\end{array}$ & + & + & + & - & + & + \\
\hline 5 & $\begin{array}{c}\text { Pirdot (Saurauria } \\
\text { vulcanii) }\end{array}$ & + & + & + & + & - & + \\
\hline
\end{tabular}

Tumbuhan yang memiliki flavonoid dan fenolik merupakan tumbuhan yang memiliki kandungan metabolit sekunder baik. Adanya senyawa alkaloid yang berasal dari tumbuhan mempunyai mekanisme sitotoksik yaitu berperan 
sebagai tubuh inhibitor (Panjaitan, 2011).

Flavonoid sebagai antioksidan yaitu melalui mekanisme pengaktifan jalur apoptis sel kanker. Efek lainnya adalah flavonoid sebagai penghambat kanker yang salah satunya menginhibisi aktivitas protein kinase sehingga menghambat jalur transduksi sinyal dari membran ke sel inti. Flavonoid juga berfungsi untuk mengurangi resistensi tumor terhadap agen kemoterapi.

Senyawa terpenoid sebagian besar memiliki struktur lipofilik yang menyebabkan kematian sel. Terpenoid juga memiliki efek sinergis bagi toksin lain dengan bertindak sebagai solven untuk memfasilitasi toksin bergerak melalui membran (Kartika, 2010). Saponin mempunyai sifat dapat menghemolisis sel darah merah dan bersifat sangat toksik bila diinjeksikan kedalam aliran darah (Krisyanella et al., 2011).

\section{KESIMPULAN DAN SARAN}

\section{A. Kesimpulan}

Ditemukan 25 jenis tumbuhan obat yang terdapat di Kawasam Hutan Adat Sinaga memiliki kandungan dan manfaat yang dapat digunakan sebagai obat.
Adapun jenis-jenis tumbuhannya sebagai antikanker adalah jambu biji (Psidium guajava), alpukat (Persea americana), gandapura (Gaultheria leucocarpa), pirdot (Saurauia vulcanii), benalu kopi (Scurrula ferruginea). Lima jenis tumbuhan obat tersebut didapatkan hasil nilai yang sangat toksik yaitu <30 ppm. Tumbuhan pirdot (Saurauria vulcanii) sebesar 3,9098 ppm, gandapura (Gaultheria leucocarpa) 4,1057 ppm, benalu kopi (Scurrula ferruginea) 16,3735 ppm, alpukat (Persea americana) 28,046 ppm jambu biji (Psidium guajava) 29,8296 ppm. Hampir semua metabolit sekunder dikatakan berperan sebagai antikanker.

\section{B. Saran}

Pemanfaaatan tumbuhan obat yang berada di Kawasan Hutan Adat Sinaga masih sangat minim dengan potensi tumbuhan obat pada tingkatan pemanfaatan untuk obat antikanker, seharusnya masyarakat memanfaatkan potensi tumbuhan obat untuk keperluan pribadi maupun dikelola dan dijadikan bisnis sebagai penambah penghasilan masyarakat sekitar, namun harus 
memenuhi izin dari pihak pengelola Hutan

\section{DAFTAR PUSTAKA}

Ajrina, A. (2013). Uji Toksisitas Akut Ekstrak Metanol Daun Garcinia Benthami Pierre terhadap Larva Artemia Salina Leach Dengan Metode Brine Shrimp Lethality Test (BSLT). Kedokteran, 2(2), 1-60.

Albertus, Dewantara, I., \& Herawatiningsih, R. (2015). Jenis dan potensi tumbuhan obat pada kawasan hutan adat gunung semarong kecamatan tayan hulu kabupaten sangau. 3, 446-455.

Febriyani, dwi putri. (2020). Efektifitas infusa dan ekstrak metanol biji mahoni (Swietenia Macrophylla King) terhadap sitotoksisitas larva udang artemia salina dengan metode bslt (Brine Shrimp Lethality Test). Skripsi Program Studi Biologi Fakultas Sains Dan Teknoogi Universitas Islam Negeri Sunan Ampel Surabaya, 2-4. http://digilib.uinsby.ac.id/42945/

Fitrah, M., \& Tahar, N. (2018). Jurnal Para Pemikir Volume 7 Nomor 1 Januari 2018 UJI TOKSISITAS fraksi daun pedada ( Sonneratia caseolaris L . ) terhadap larva udang ( artemia salina leach) dengan menggunakan metode Brine Shrimp Lethality Test ( BSLT ) Jurnal Para Pemikir Volume 7 Nomo. 7, 181-186.

Harijanto, H., Hapid, A., Wahid, A., Fakultas, D., Universitas, K., Fakultas, A., \& Universitas, K. (2017). Pemanfaatan Jenis-Jenis Tumbuhan Berkhasiat Obat Desa Mantikole Kecamatan Dolo Barat Kabupaten
Adat Sinaga.

Hassan, O. (2007). Pithecellobium jiringa. Ministry of Education. http://btpnkedah.moe.edu.my/imejan/

Jazilah, N., Fasyah, A. G., Ningsih, R., \& Abtokhi, A. (2014). Uji Toksisitas Ekstrak Daun Binahong ( Anredera cordifolia (Ten.) Steenis) Terhadap Larva Udang Artemia Salina Leach Dengan Metode Brine Shrimp Lethality Test (BSLT) Nur Jazilah, A.Ghanaim Fasya, Rachmawati Ningsih, Ahmad Abtokhi. Alchemy, $3(2), 118-124$.

KATILI, A. S. (2015). Inventarisasi tumbuhan obat dan kearifan lokal masyarakat Etnis Bune dalam memanfaatkan tumbuhan obat di Pinogu, Kabupaten Bonebolango, Provinsi Gorontalo. 1, 78-84. https://doi.org/10.13057/psnmbi/m010 112

Manongko, P. S., Sangi, M. S., \& Momuat, L. I. (2020). Uji Senyawa Fitokimia dan Aktivitas Antioksidan Tanaman Patah Tulang (Euphorbia tirucalli L.). Jurnal MIPA, 9(2), 64. https://doi.org/10.35799/jmuo.9.2.202 0.28725

Maria Tensiana Tima, S. W. \& M. (2020). Etnobotani Tanaman Obat Di Kecamatan Nangapanda Kabupaten Ende Nusa Tenggara Timur (Ethnobotanical Study of Medicinal Plants Used in Nangapanda, Ende, Nusa Tenggara Timur). Faloak, 4(1), 23-38. 
Panjaitan, ridho bertomi. (2011). Uji toksisitas akut ekstrak kulit batang pulasari (Alyxiae cortex) dengan metode brine shrimp lethality test (BST).

Sinaga, I., Rosliana, \& Riyanto. (2018). Uji Toksisitas (Lc50 - 24 Jam) Ekstrak Kulit Jengkol (Pithecellobium Jiringa) Terhadap Larva Udang Artemia salina Leach. Biosains, 4(2).

Suhendra, C. P., Widarta, I. W. R., \& Wiadnyani, A. A. I. S. (2019). Pengaruh Konsentrasi Etanol Terhadap Aktivitas Antioksidan Ekstrak Rimpang Ilalang (Imperata Cylindrica (L) Beauv.) Pada Ekstraksi Menggunakan Gelombang Ultrasonik. Jurnal Ilmu Dan Teknologi Pangan (ITEPA), $\quad 8(1), \quad 27$. https://doi.org/10.24843/itepa.2019.v0 8.i01.p04

Sukandar, D., Hermanto, S., \& Lestari, E. (2008). Uji Toksisitas Ekstrak Daun Pandan Wangi (Pandanus amaryllifolius Roxb.) Dengan Metode Brine Shrimp Lethality Test (BSLT). Jurnal Kimia VALENSI, 1(2), 63-70. https://doi.org/10.15408/jkv.v1i2.217 